\title{
PERAN ORANG TUA DAN GURU DALAM MENGEMBANGKAN KARAKTER ANAK/PESERTA DIDIK DI ERA MODERN
}

\author{
Muhammad Mona Adha ${ }^{1}$, Eska Prawisudawati Ulpa ${ }^{2}$ \\ ${ }^{1}$ Universitas Lampung, Lampung, Indonesia \\ ${ }^{2}$ Universitas Islam Negeri Raden Intan Lampung, Lampung, Indonesia \\ mohammad.monaadha@ fkip.unila.ac.id
}

\begin{abstract}
ABSTRAK
Pendidikan merupakan suatu hal yang paling penting untuk membentuk kepribadian seseorang. Penanaman dan penguatan karakter peserta didik era modern saat ini memiliki tantangan tersendiri khususnya bagi para guru di Indonesia. Tantangan juga dihadapi oleh diri siswa itu sendiri ditengah perkembangan teknologi dan informasi yang super cepat dan dapat dijangkau dengan mudah. Guru harus menyesuaikan keadaan perubahan situasi modern saat ini dengan perkembangan diri siswa, agar nilai positif menjadi transformasi diri untuk memiliki karakter yang baik selaras dengan budaya atau adat istiadat yang melekat kuat di Indonesia. Sebagai bangsa yang kuat di era modern ini haruslah mempunyai prinsip-prinsip dalam kehidupan berbangsa dan bernegara. Implementasi pendidikan karakter di sekolah diperlukan kompetensi guru yang mampu turut berkompetisi di era modernisasi ini. Di era modern saat ini penanaman dan pengembangan nilai-nilai karakter menemui hambatan yang cukup signifikan dibandingkan dengan berpuluh-puluh tahun yang lalu, hal tersebut turut dipengaruhi oleh perkembangan yang terjadi di sekitar siswa maka dari itu kreativitas dan inovasi antara orang tua dan pendidik harus terus dikembangkan. Intensitas komunikasi antara siswa, orang tua, dan guru dilakukan dua arah dan memposisikan diri sebagai pendengar yang baik bagi siswa saat berada di rumah dan di sekolah.
\end{abstract}

Kata Kunci: Guru, Indonesia, Karakter Siswa, Modern, Peran Orang Tua

\begin{abstract}
Education is the most important thing in shaping a person's personality. Cultivating and strengthening the character of students in the modern era now has its challenges, especially for teachers in Indonesia. The students themselves also face challenges amid technology and information development that is super fast and reached easily. Teachers must adapt to the changing circumstances of the current modern situation with students themselves so that positive values become self-transformation to have a good character in harmony with the culture or customs that are strongly inherent in Indonesia. As a strong nation in this modern era, it must have principles in the life of the nation and state. Character education implementation in schools requires teacher competence who can compete in this modernization era. In the modern era, the cultivation and development of character values encountered significant obstacles compared to decades ago, this is also influenced by developments that occur around students, therefore creativity and innovation
\end{abstract}


between parents and educators must continue. developed. Communication intensity between students, parents, and teachers carried out in two directions and positions themselves as good listeners for students at home and at school.

\section{Keywords: Indonesia, Student Character, Modern, Parents Participation, Teacher}

\section{PENDAHULUAN}

Pesatnya kemajuan informasi dan teknologi di abad 21 ini harus bersamaan dengan kemampuan siswa, orang tua, dan guru untuk bersinergi membentuk karakter anak yang kuat sebagai bekal di masa depan di tengah-tengah kehidupan modern saat ini. Degradasi moral pada beberapa anak-anak muda khususnya siswa dipengaruhi oleh lingkungan dan ketidakmampuan dalam aspek digital literacy yang masih rendah, sehingga masih belum bisa menentukan informasi benar-benar dibutuhkan sebagai sumber belajar. Sikap dan bentuk karakter saat ini di era modern tentu berbeda dengan karakter pada masa lalu di tahun 1970 atau 1980, dimana pada beberapa puluh tahun kebelakang belum begitu dipengaruhi oleh perkembangan digital dan informasi seperti sekarang ini. Siswa sebagai pengguna dari media canggih yang berkembang sangat cepat dikhawatirkan menerima segala informasi yang ada tanpa adanya filter informasi yang menyumbang pembentukan karakter siswa itu sendiri.

Siswa tidak bisa dibiarkan sendiri (berbeda dalam konteks belajar mandiri) melainkan harus selalu didampingi dan diberikan arahan oleh orang tua dan guru. Pola komunikasi yang dibangun antara sekolah dan rumah menjadi poin penting dari bagian untuk memperkuat karakter pada diri siswa. Mendengarkan apa yang menjadi permasalahan atau kesulitan pada diri siswa kepada orang tua dan guru merupakan langkah yang tepat agar mendapatkan sebuah jawaban yang mengarahkan anak tersebut dari perspektif orang yang lebih dewasa dan berfokus pada masa depan anak. Komunikasi berkontribusi di dalam memberikan ruang pertemuan dan pendekatan yang dilakukan oleh orang tua dan guru untuk menjalin hubungan yang kuat dengan didasari oleh kepercayaan yang dibangun diantaranya (Zulyan et al., 2014).
Fasilitas saat ini dapat dengan mudah dicari dan didapatkan untuk mendukung proses pembelajaran siswa baik di rumah dan di sekolah, namun bukan berarti semua pembelajaran diserahkan kepada teknologi. Teknologi memiliki keterbatasan di dalam mengungkapkan rasa simpati dan empati dalam hubungan antar siswa, orang tua, dan guru. Perkembangan ilmu pengetahuan dan teknologi di era digital saat ini menuntut peran serta orang tua dan guru untuk saling berdiskusi dan menemukan formula yang tepat di dalam memperkuat karakter anak (siswa) agar dapat memilih aktivitas yang positif yang berguna di masa depan. Orang tua membangun kehangatan dan komunikasi di rumah, sementara itu guru merancang dan melaksanakan kegiatan belajar dan pembelajaran yang konstruktif dalam bentuk saintifik yang interaktif.

Strategi yang dilakukan di dalam kelas untuk membentuk karakter siswa adalah dengan menciptakan aktivitas kecil dan ringan yang mengajak setiap siswa untuk memberikan pelayanan yang terbaik dari dirinya melalui bekerjasama dengan temanteman di kelas (Saputro et al., 2013), contohnya menyapu kelas, merapikan meja dan kursi di kelas, secara bergantian mempersiapkan alat-alat tulis yang akan digunakan oleh guru di dalam kelas, dan bersama-sama menjaga kebersihan di dalam kelas, serta merapihkan buku-buku yang ada di lemari di dalam kelas. Kyushoku adalah program school lunch atau makan siang bersama di dalam kelas yang dilakukan di Jepang sejak tahun 1954 di sekolah tertentu dan telah secara resmi program tersebut dimasukkan ke dalam kurikulum. Program bertujuan tidak hanya membentuk karakter siswa dalam hal bertugas melayani temannya saat mengambil makan siang, disisi lain Kyushoku mengajarkan sikap kepada siswa betapa pentingnya makanan yang sehat itu, 
dimana program ini dilaksanakan di tingkat public elementary schools.

Aktivitas di atas sepertinya terlihat ringan, namun sebenarnya kegiatan tersebut mampu membentuk sikap dan karakter siswa di masa depan. Implementasi pola aktivitas sederhana yang secara terus menerus dilakukan dapat menambah pengalaman hidup siswa. Peran orang tua dan guru adalah mengingatkan dan memberikan penguatan dengan cara berkomunikasi dan menjadi pendengar yang baik bagi mereka (Zulyan et al., 2014). Perubahan perkembangan zaman yang begitu cepat menuntut guru harus mempunyai kompetensi yang memadai karena jika suatu perkembangan zaman tidak dibarengi dengan sebuah kemampuan yang memadai maka perkembangan tersebut akan berdampak negatif dalam kelangsungan hidup manusia. Artikel ini lebih mengutamakan dalam membangun suasana yang mampu mengikutsertakan hati dan sikap bertindak dari seorang siswa di dalam memperkuat karakter dan prinsip diri yang dimiliki.

\section{METODE PENELITIAN}

Artikel ini menggunakan pendekatan penelitian studi kepustakaan (library research) yang diaplikasikan dengan menggunakan literatur baik berupa buku, jurnal, prosiding, dan dokumen lain yang relevan dengan studi riset. Penelitian studi kepustakaan dilakukan dengan mengumpulkan data (primer dan sekunder), mengidentifikasi dan menghimpun informasiinformasi dari konsep yang ada. Data dan informasi yang telah dikumpulkan dilanjutkan kepada tahap kajian analisis yang disertai dengan refleksi dan interpretasi penulis sehingga memberikan sebuah kesimpulan yang berguna untuk menemukan jawaban atau informasi yang dibutuhkan dalam riset. Analisis artikel dibutuhkan untuk menemukan konsep kajian 1) Peran orang tua dan guru termasuk dukungan orang tua dan guru di dalam pelaksanaan pembelajaran; 2) Penguatan karakter dan sikap/perilaku anak/siswa di dalam perkembangan teknologi, informasi, dan komunikasi. Perkembangan teknologi, informasi, dan komunikasi sangat dibutuhkan di dalam proses pembelajaran dan sekaligus mengembangkan dan memperkuat kompetensi kewarganegaraan dan karakter siswa sebagai pembelajar abad atau era modern. Acuan utama dalam konteks karakter siswa menggunakan teori dari Thomas Lickona mengenai komponen karakter yang dimiliki seorang anak/individu.

\section{HASIL DAN PEMBAHASAN}

\section{Konsistensi Lingkaran Karakter: Keluarga, Sekolah, dan Masyarakat}

Karakter dalam konteks Taman Siswa oleh Ki Hadjar Dewantara dicerminkan dalam wujud keikhlasan, kerjasama, kemandirian, saling menyayangi, dan keadaban (Majelis Luhur Persatuan Taman Siswa, 2013). Ki Hadjar Dewantara memberikan sudut pandang karakter yang cukup penting baik dari sisi keluarga, sekolah, dan masyarakat yaitu menumbuhkan budi pekerti untuk semua individu (termasuk rakyat). Sistem Among yang diimplementasikan oleh $\mathrm{Ki}$ Hadjar Dewantara menunjukkan bahwa kemandirian menjadi indikator karakter bagi siswa agar memiliki pengalaman dan dikontribusikan ke dalam masyarakat. Konsistensi lingkaran karakter di dalam artikel ini sejalan dengan konsep Tri Pusat Pendidikan yang dimunculkan oleh Ki Hadjar Dewantara dalam membangun aspek fisik dan spiritual yang tangguh di lingkungan keluarga, sekolah, dan masyarakat. Dengan demikian, konsep diri yang dibutuhkan untuk memperkuat karakter dalam hal ini adalah orang tua dan guru yang tidak hanya memahami ilmu pengetahuan tetapi juga berkepribadian (berperilaku dan mewarisi nilai-nilai kebaikan).

Lingkaran dasar hidup yang membentuk watak manusia di dalam perjalanan Taman Siswa disebut "concentrische cirkels". Lingkaran pembentukan watak pribadi insan manusia saat itu lebih diarahkan kepada persatuan umat manusia dan keharmonisan. Lingkaran karakter dimasa Taman Siswa dibentuk oleh tiga titik antara lain: 1) lingkaran keluarga; 2) lingkaran kebangsaan; dan 3) lingkaran kemanusiaan (Majelis Luhur Persatuan Taman Siswa, 2013). Apabila lingkaran ini dilakukan dengan sebaik- 
baiknya maka persatuan dan keharmonisan diri setiap individu maupun masyarakat secara kodrat-iradatnya akan menjadi lebih kuat. Pada lingkaran ini, siswa tumbuh di dalam pola aktivitas kebudayaan, komunikasi antar individu, memahami dan menjalankan sikap nasionalisme, dan memiliki rasa simpati dan empati terhadap individu yang lain. Oleh karena itu, metode pengajaran dan peranan orang tua di dalam membangun sikap mental anak-anak mampu menghasilkan budi pekerti dan mewujudkan kehidupan sebaik-baiknya.

Aktivitas belajar dan pembelajaran di era modern sekarang tidak hanya dilakukan secara konvensional saja akan tetapi juga dilakukan secara online atau dalam jaringan. Masa pandemik Covid-19 yang telah masuk ke Indonesia sejak Maret 2020 telah membawa perubahan di dalam format belajar dari tatap muka di kelas seperti biasanya menjadi pembelajaran online menggunakan aplikasi belajar digital dari rumah. Perubahan yang terjadi seperti ini, siswa membutuhkan dukungan baik dari orang tua dan guru untuk belajar secara online sekaligus dengan tetap memperkuat karakter anak/siswa selama proses belajar berlangsung. Berdasarkan perubahan format belajar tersebut, komunikasi dan menjadi pendengar yang baik bagi anak/siswa menjadi salah satu alternatif agar anak/siswa dapat terus termotivasi di dalam belajar yang dilaksanakan selama masa pandemik Covid-19, dan pembelajaran berbasis komputer daring serta beragam pilihan komunikasi yang dapat digunakan guru dan siswa (Sutisna, 2016).

Dalam UU No. 12 Tahun 2005 tentang Guru dan Dosen disebutkan bahwa kompetensi guru dikelompokkan menjadi 4 yang pertama yaitu kompetensi pedagogik, yang kedua kompetensi kepribadian, kompetensi sosial dan terakhir kompetensi profesional. Kompetensi pedagogik merupakan kemampuan yang dimiliki guru dalam mengelola pembelajaran dalam kelas bersama peserta didik. Kompetensi kepribadian merupakan suatu kemampuan kepribadian seorang guru sebagai teladan yang mempunyai akhlak mulia, arif, berwibawa dan memiliki martabat yang tinggi. Ketika Kompetensi sosial yakni merupakan suatu kemampuan yang dimiliki oleh guru untuk melakukan komunikasi dan interaksi secara efektif dan efisien baik kepada peserta didik seluruh orang tua wali maupun masyarakat. Kompetensi profesional dalam merupakan suatu kemampuan guru dalam menguasai materi pembelajaran secara luas dan mendalam.

Karakter menurut Lickona terbagi atas beberapa bagian yang tercakup di dalamnya. Sebagaimana yang dikemukakan oleh Lickona di bawah ini:

Character so conceived has three interrelated parts: moral knowing, moral feeling, and moral behavior. Good character consists of knowing the good, desiring the good, and doing the good, habits of the mind, habits of the heart, and habits of action. All three are necessary for leading a moral life, all three make up moral maturity. When we think about the kind of character we want for our children, it's clear that we want them to be able to judge what is right, care deeply about what is right, and then do what they believe to be right, even in the face of pressure from without and temptation from within (1991: 51).

Berdasarkan pendapat Lickona di atas dapat dijelaskan bahwa karakter terdiri atas tiga korelasi antara lain moral knowing, moral feeling, dan moral behavior. Karakter itu sendiri terdiri atas, antara lain: mengetahui hal-hal yang baik, memiliki keinginan untuk berbuat baik, dan melaksanakan yang baik tadi berdasarkan atas pemikiran, dan perasaan apakah hal tersebut baik untuk dilakukan atau tidak, kemudian dikerjakan. Ketiga hal tersebut dapat memberikan pengarahan atau pengalaman moral hidup yang baik, dan memberikan kedewasaan dalam bersikap.

Karakter sebagai Transformasi Moral Diri, terdapat 5 Kriteria "contoh Moral" yakni: 1) Komitmen berkelanjutan untuk citacita moral; 2) Konsistensi antara cita-cita seseorang dan cara mencapainya; 3) Kesediaan untuk mengorbankan kepentingan pribadi; 4) Kapasitas untuk mengilhami orang lain; dan 5) Kerendahan hati tentang kepentingan sendiri. Colby dan Damon 
menemukan bahwa dalam proses kehidupan, setiap individu yang luar biasa ini mengembangkan tujuan pribadi dengan melibatkan sebuah transformasi moral. Pelajaran bagi kita sebagai guru atau orang tua: bahwa pertama memberikan kaum muda kesempatan untuk memikirkan dan menetapkan tujuan bermanfaat yang akan mengembangkan karakter untuk membutuhkan tujuan hidup. Kedua teladan yang memproses diri kita sendiri, sehingga anak-anak muda memiliki orang dewasa yang mempunyai tekad idealisme yang tinggi (Lickona, 2012).

Oleh hati, olah pikir, olah raga dan olah rasa dan karsa tidak bisa dibentuk dalam waktu yang instan, melainkan memperkuat karakter siswa adalah dengan mengembangkan suasana pembelajaran yang aktif interaktif, dan dilandasi pemehaman secara mendalam terhadap perkembangan anak/siswa. Pengintegrasian pendidikan karakter dalam pembelajaran dapat dilakukan dengan penguatan nilai-nilai karakter dalam semua bidang mata pelajaran yang diajarkan di sekolah dan dalam pelaksanaan kegiatan pembelajaran (Zulyan et al., 2014; Alifah et al., 2021; Hartino et al., 2021). Hal yang dapat mendukung keberhasilan pembelajaran di era teknologi salah satunya adalah dengan memanfaatkan media pembelajaran. Pendapat yang dikemukakan bahwa media pembelajaran mendukung kegiatan belajar di mana fungsi atau kegunaan media antara lain membuat konkrit konsep yang abstrak, memungkinkan peserta didik berinteraksi langsung dengan lingkungannya, memungkinkan kesegaran pengamatan dan pandangan bagi pengamatan belajar peserta didik, membangkitkan motivasi belajar, menyajikan suatu informasi belajar secara konsisten dan dapat diulangi maupun disimpan menurut kebutuhan peserta didik (Sadiman, 1986).

Beberapa kesulitan yang dialami oleh oleh pendidik dalam mengimplementasikan nilai-nilai karakter di dalam pembelajaran berbasis online dikarenakan masih banyak guru yang belum memanfaatkan media secara maksimal. Kalau saat ini masih terfokus pada buku bacaan saja. Dalam meningkatkan efektivitas dan efisiensi pembelajaran perlu dilakukannya pengembangan berbagai model pembelajaran yang kreatif dan inovatif. Hal ini perlu dilakukan agar proses pembelajaran tidak terkesan menonton karena monoton dapat menimbulkan kebosanan sehingga akan menghambat perkembangan pengetahuan dan karakter dari peserta didik. Maka dari itu peran dari media dalam proses pembelajaran menjadi penting karena akan menjadikan proses pembelajaran tersebut menjadi lebih bervariasi dan tidak membosankan mampu merangsang emosional peserta didik sehingga dapat terjadinya proses pembelajaran yang interaktif.

\section{Penguatan Sikap dan Karakter Anak/Peserta Didik Era Modern Dalam Perubahan Teknologi, Informasi, dan Komunikasi}

Era modern saat ini siswa telah mendengar dan mengenal seperti google, zoom, google classroom, Edmodo, game online, windows, wifi, byte, cloud, application, email, android, dan masih banyak kata lain yang identik dengan perubahan teknologi, informasi, dan komunikasi dengan cepat. Perubahan alat-alat komunikasi, perangkat kerja yang digunakan sehari-hari oleh setiap orang pada umumnya, dan oleh siswa pada khususnya membawa perubahan tersendiri dalam hal interaksi, informasi yang masuk, budaya, gaya hidup dan masih banyak faktor lain. Bentuk penguatan sikap dan karakter yang sedapat mungkin dilakukan oleh orang tua dan guru adalah memberikan bekal digital literacy, membuka ruang komunikasi untuk berdiskusi satu sama lain, dan mendengarkan info atau pendapat/cerita atau hal-hal apa saja yang ingin disampaikan oleh anak/siswa.

Baik orang tua dan guru tidak hanya berdiam diri, namun keduanya melakukan peningkatan/meningkatkan kemampuan diri baik secara pengetahuan dan teknis di dalam perkembangan perangkat teknologi, informasi, dan komunikasi agar orang tua dan guru dapat memahami dan mengerti secara langsung mengenai kabar/informasi/berita yang berada di sekitar diri anak/siswa. Justru dalam era modern saat ini yang serba canggih 
dan mudah mengakses informasi dalam genggaman melalui fasilitas telepon pintar, orang tua dan guru mampu mengarahkan anak mereka atau siswa untuk melihat dan menggunakan fasilitas tersebut dalam sudut pandang yang positif sehingga dapat mendukung proses belajar mereka dan meningkatkan pengetahuan mereka selaku individu. Anak/siswa dalam era modern ini dibesarkan dalam lingkungan yang serba digital dan berselancar di dunia maya, hal tersebut tidak dapat dihindari, tentu hal ini memberikan tantangan kepada orang tua dan guru untuk mengarahkan anak/siswa menggunakan internet sesuai pada porsinya dan bijak bagi mereka sebagai pelajar (Perdana \& Adha, 2020).

Dalam aktivitas belajar dan pembelajaran seorang guru tidak hanya menjalankan tugasnya sebagai pemberi ilmu pengetahuan saja melainkan seorang guru dituntut agar mampu menanamkan nilai serta dapat membangun karakter peserta didik secara berkelanjutan dan berkesinambungan untuk menuju seorang yang mempunyai martabat yang tinggi (Wijaya et al., 2020). Kegiatan pendidikan dan pembelajaran merupakan suatu proses kegiatan interaksi antara guru dan peserta didik. Dalam pendidikan guru berperan sebagai model pengembangan karakter dan membuat penilaian dan keputusan profesional yang didasarkan pada kebajikan sosial dan moralitas. Pada hakekatnya setiap peserta didik mengharapkan seorang guru yang dapat menjadi contoh atau model teladan baginya.

Peningkatan kemampuan guru di dalam era digital menjadi sangat penting agar dapat selaras dengan pemahaman dan kemampuan siswa di dalam menggunakan atau mengoperasikan serta memanfaatkan fasilitas pendukung tersebut untuk memperkaya pembelajaran. Profesionalisme guru, kompetensi guru dapat ditingkatkan dan dijaga kualitasnya melalui in house training, pelatihan, diklat, workshop dan lain-lain agar dapat melakukan penyegaran keilmuan yang sesuai dengan bidang kehalian guru masingmasing. Kepribadian yang terpuji yang dimiliki guru menjadi teladan bagi siswa untuk mencontoh atau menjadikan guru tersebut sebagai inspirasi yang secara tidak langsung membentuk atau memperkuat karakter mereka yang mereka dapatkan melalui proses belajar dan kontemplasi diri untuk menjadi individu yang semakin baik dan semakin baik. Sebagai seorang guru harus mampu mengembangkan potensi dirinya untuk dapat melakukan proses pembelajaran secara kreatif inspiratif dan cerdas agar seorang guru memiliki suatu keunggulan guna menghadapi tantangan yang semakin canggih. Untuk itulah diperlukan guru yang inspiratif dalam proses pembelajaran (Butho, 2016).

Media pembelajaran memiliki peran penting dalam menunjang kualitas proses belajar mengajar. Media juga mampu membuat proses pembelajaran menjadi lebih menarik dan menyenangkan, media pembelajaran membantu dalam merangsang pikiran peserta didik yang saran perhatian dan meningkatkan keterampilan pembelajaran sehingga dapat mendorong terjadinya proses pembelajaran yang efektif. (Purwono, et al., 2014). Efektivitas suatu proses pembelajaran sangat dipengaruhi oleh faktor metode pembelajaran dan media pembelajaran yang digunakan kedua hal tersebut saling berkaitan dimana pendidik pemilihan metode tertentu akan berpengaruh terhadap jenis media yang akan digunakan.

Ciri utama media menjadi tiga unsur pokok yaitu audio, visual dan gerak (Sanjaya, 2006: 212). Dari ketiga Pembagian jenis media agar dapat dimanfaatkan salah satu sesuai dengan kondisi dan topik pelajaran. Media pembelajaran tersebut dapat digunakan oleh pendidik dalam proses pembelajaran agar pembelajaran lebih interaktif. Terkait dengan pendidikan karakter di era teknologi guru dapat menggunakan media bagi berubah audio visual maupun gerak tergantung dengan kesesuaian materi yang diajarkan. Dengan memanfaatkan media-media tersebut pembelajaran akan jauh lebih efektif dan tidak monoton dan mampu merangsang yang masih ada peserta didik. Dengan kata lain media pembelajaran adalah suatu alat yang berfungsi untuk menyampaikan materi pelajaran dan pesan-pesan yang terkandung dalam sebuah pembelajaran. (Fry, Ketteridge \& Marshal, 2003). 
Lembaga pendidik dan guru dihadapkan pada tuntutan yang semakin berat terutama untuk mempersiapkan peserta didik agar mampu menghadapi dinamika-dinamika perubahan yang berkembang dengan begitu besar. Lingkungan sekolah atau lingkungan pendidikan guru saat ini memiliki peran yang sangat besar dalam membentuk karakter peserta didik. Peran seorang guru tidak hanya sekedar sebagai pemberi materi pembelajaran saja pada bidang akademis akan tetapi juga harus mampu menanamkan karakter moral dan budaya kepada peserta didik. Guru merupakan seorang teladan seorang model dan mentor bagi peserta didik dalam mewujudkan sikap dan perilaku yang berkarakter yang meliputi olah pikir olah hati dan olah rasa. Sekolah dan guru harus mendidik karakter khususnya melalui pengajaran yang dapat mengembangkan rasa hormat dan tanggung jawab (Lickona, 1991).

Pengembangan pendidikan karakter di sekolah merupakan tanggung jawab bersama. Dalam menanamkan dan mengembangkan pendidikan karakter dapat dilakukan dengan cara mengintegrasikan ke dalam proses pembelajaran. Sekolah merupakan tempat dalam mengembangkan pendidikan karakter. Seorang pendidik mempunyai tanggung jawab yang begitu besar dalam membentuk generasi yang memiliki karakter berbudaya dan bermoral. Undang-undang yang telah ditetapkan tentang guru dan dosen menyatakan bahwa guru sebagai pendidik profesional mempunyai tugas utama mendidik mengajar membimbing mengarahkan melatih menilai dan mengevaluasi peserta didik.

Guru yang memiliki kompetensi adalah guru yang dalam pelaksanaan pembelajaran selalu melakukan hal baru. Kreativitas seorang pendidik merupakan hal yang sangat penting karena dengan adanya kreativitas tersebut guru dapat menemukan cara yang lebih baik dalam melayani peserta didik. Kreativitas merupakan sesuatu yang bersifat universal dan merupakan ciri aspek dunia kehidupan sekitar kita. Kreativitas bukan hanya sekedar menciptakan hal yang belum ada, kreativitas itu sendiri adalah dapat memanfaatkan hal-hal yang sudah ada yang dapat mendukung dalam proses pembelajaran, sehingga di situlah hal baru yang belum pernah dirasakan dialami oleh guru dan siswa.

Peran seorang guru sebagai pendidik merupakan peran yang berkaitan dengan tugas-tugas dan tanggung jawabnya dalam memberi bantuan dan dorongan, melakukan pengawasan dan pembinaan kepada peserta didik dengan mendisiplinkan anak-anak agar patuh terhadap peraturan peraturan yang dibuat oleh sekolah dan norma dalam kehidupan bermasyarakat. Terkait tugas-tugas seorang pendidik di atas adalah untuk meningkatkan pertumbuhan dan perkembangan peserta didik agar memperoleh pengalaman pengalaman lebih lanjut. Seorang guru haruslah memiliki kepribadian yang mencerminkan seorang pendidik. Karena sejatinya seorang pendidik adalah model bagi anak didiknya, maka dari itu pendidik harus memiliki kepribadaian yang baik.

\section{Kompetensi Orang Tua dan Guru Dalam Mengembangkan Karakter Anak}

Kemampuan di dalam mendidik anak baik yang oleh orang dan tua dan guru berpengaruh di dalam membentuk sikap mental anak (saat berada di rumah) atau siswa (saat berada di sekolah). Kuncinya adalah keteladanan, contoh-contoh, dan ruang terbuka di dalam berkomunikasi dimana orang tua dan guru turut terlibat di dalam mendengarkan apa yang ingin disampaikan oleh anak tadi dalam berbagai perspektif. Anak/siswa membutuhkan ruang komunikasi dimana sebagai individu ingin memiliki kesempatan untuk didengarkan aspirasi, komentar maupun pendapat agar menemukan sebuah solusi atau jawaban, atau informasi yang menjadi harapan anak atau siswa tersebut. Meningkatkan atau melatih kompetensi oleh orang tua dan guru dari waktu ke waktu menjadi signifikan untuk dilakukan mengingat perkembangan dunia modern saat ini menghadirkan berbagai tantangan-tantangan baru yang menuntut kompetensi anak/siswa untuk selaras dan mengikuti perkembangan tersebut. Bimbingan, arahan dalam konteks komunikasi yang terbuka tersebut maka secara tidak langsung dapat meningkatkan kualitas, 
prestasi, kontribusi dan kepercayaan diri bagi anak/siswa.

Kompetensi orang tua dan pendidik (guru) di era digital merupakan kemampuan yang menuntut kecakapan seorang pendidik dalam menggunakan akses teknologi dan informasi. Blyznyuk, (2018) membagi kompetensi detail pendidik ke dalam beberapa bentuk yaitu information, communication, Edition content Creation, security educational problem solving. Berdasarkan penjelasan tersebut dapat dipahami bahwa kompetensi yang harus dimiliki oleh seorang pendidik di era digital yang pertama adalah seorang pendidik harus memiliki kemampuan literasi literasi di sini yang dimaksud adalah mampu memilih dan memilah mengevaluasi dan informasi yang cocok untuk menunjang proses pembelajaran. Kompetensi komunikasi yaitu keterampilan seorang pendidik untuk dapat berinteraksi terlibat dalam berbagai kerjasama melalui teknologi digital. Kompetensi yang terakhir yaitu sebuah kemampuan pendidik untuk dapat menciptakan konten-konten pembelajaran digital konten tersebut dapat berupa animasi foto video atau lain sebagainya yang dapat meningkatkan kreativitas seorang pendidik itu sendiri.

Selain kompetensi tersebut Kementerian Pendidikan dan Kebudayaan menyebutkan ada 5 kompetensi yang harus dipersiapkan guru memasuki era revolusi industri 4.0 yaitu pertama educational competence, kompetensi pembelajaran berbasis internet sebagai basic skill. kedua, competence for technological commercialization, artinya adalah seorang guru harus memiliki kompetensi yang akan membawa peserta didik memiliki setiap enterpreneurship dengan teknologi atas hasil karya inovasi peserta didik itu sendiri. ketiga, competence in globalization, yaitu seorang pendidik tidak gagap terhadap berbagai budaya dan mampu menyelesaikan persoalan dalam pendidikan. Keempat, competence in future strategies, kemampuan untuk memprediksi dengan tepat Apa yang akan terjadi di masa depan dan bagaimana strateginya. Kelima, conselor competence, yaitu kompetensi guru untuk memahami bahwa ke depan adalah peserta didik bukan hanya kesulitan dalam memahami materi ajar tetapi juga terkait permasalahan psikologi akibat perkembangan zaman (Kemendikbud, 2018).

Istilah karakter dalam bahasa Latin charassein yang artinya mengukir corak yang tetap dan tidak terhapus. Karakter merupakan perwujudan dari watak yang melekat dalam diri seseorang yang yang terbentuk dari hasil internalisasi yang digunakan sebagai dasar dalam berperilaku sehingga menimbulkan suatu ciri khas pada seseorang. Karakter seseorang akan berkembang dengan baik apabila mendapat suatu penguatan yang tepat yaitu dalam bentuk pendidikan. Pembinaan karakter terhadap generasi muda dapat ditempuh dengan berbagai cara salah satunya melalui pendidikan yang dilakukan secara terprogram bertahap dan berkesinambungan (Hasan, 2010: 6). Dalam menanamkan pendidikan karakter hasil tidak akan terlihat dalam waktu yang cepat karena dalam pembentukan karakter memerlukan waktu yang panjang dan membutuhkan upaya yang kuat, setidaknyanya melalui pendidikan karakter generasi mempunyai ketahanan diri yang kuat dalam menghadapi tantangan dari luar.

Pendidikan karakter merupakan suatu penciptaan lingkungan sekolah yang membantu peserta didik dalam perkembangan etika sikap tanggung jawab melalui model pembelajaran karakter yang baik melalui nilai-nilai yang universal (Berkowitz \& Bier, 2005:7). Nilai-nilai yang terkandung dalam karakter sudah seharusnya ditanamkan dalam diri peserta didik Sehingga dalam kehidupan kehidupan mereka mampu mengaplikasikan karakter tersebut dalam kehidupan sehari-hari di mana tempat mereka tinggal.

Dalam Undang-undang Nomor 20 tahun 2003 Tentang Sistem Pendidikan Nasional pasal 3 dinyatakan bahwa pendidikan nasional berfungsi mengembangkan kemampuan dan membentuk watak serta peradaban bangsa yang bermartabat dalam rangka mencerdaskan kehidupan bangsa, bertujuan untuk berkembangnya potensi peserta didik agar menjadi manusia yang beriman dan bertakwa kepada Tuhan Yang Maha Esa, berakhlak mulia, sehat, berilmu, cakap, kreatif, mandiri, 
dan menjadi warga negara yang demokratis serta bertanggung jawab. Salah satu cita-cita bangsa Indonesia adalah membentuk warga negara yang memiliki kecerdasan sekaligus karakter. Sehubung dengan ketetapan undangundang tentang sisdiknas serta tujuan pendidikan nasional yang telah ditetapkan oleh pemerintah bahwa pendidikan di masa yang akan datang harus memiliki mutu dan berkualitas dibanding dengan pelaksanaan pendidikan yang telah berlangsung saat ini.

Terdapat tiga komponen karakter yang baik (component of Good character), yaitu moral knowing atau pengetahuan tentang moral, moral feeling atau perasaan tentang moral, dan moral action atau perbuatan moral (Lickona 1992). Hal tersebut diperlukan agar supaya anak mampu memahami merasakan dan mengerjakan sekaligus nilai-nilai kebijakan. Pendidikan karakter adalah pendidikan budi pekerti plus yaitu melibatkan aspek pengetahuan (kognitive), perasaan (feeling) dan tindakan (action) tanpa ketiga aspek ini maka pendidikan karakter tidak akan efektif. Pengertian yang disampaikan oleh memperlihatkan bahwa adanya proses perkembangan yang melibatkan ranah pengetahuan rendah perasaan dan rendah tindakan sekaligus memberikan suatu dasar yang kokoh untuk dapat membangun Pendidikan karakter yang menyeluruh. Pengertian di atas juga menekankan bahwa seharusnya dalam proses pendidikan dapat dilakukan dengan cara kegiatan-kegiatan yang akan mengantarkan peserta didik menuju seseorang yang memiliki kemampuan berpikir kritis mengenai problem etika dan moral.

Dalam pendidikan karakter yang diintegrasikan di dalam mata pelajaran ada hal-hal yang perlu diperhatikan seperti: a) kebijakan sekolah dan dukungan administrasi sekolah terhadap pendidikan karakter yang meliputi visi dan misi pendidikan karakter sosialisasi dokumen pendidikan karakter dan lain-lain. b) kondisi lingkungan sekolah meliputi sarana dan prasarana yang mendukung lingkungan yang bersih kantin kejujuran ruang keagamaan dan lain-lain. c) pengetahuan dan sikap guru yang meliputi konsep pendidikan karakter cara membuat perencanaan pembelajaran perangkat pembelajaran kurikulum silabus RPP dan bahan ajar penilaian pelaksanaan pendidikan karakter terintegrasi dalam mata pelajaran dan lain-lain. d) peningkatan kompetensi guru. e) dukungan masyarakat. (Tarmansyah, et. al, 2012:15).

Pendidikan karakter di Indonesia merupakan suatu gerakan nasional untuk menciptakan sekolah dalam membina generasi muda yang beretika memiliki sikap tanggung jawab dikarenakan pendidikan karakter lebih menekankan pada aspek nilainilai yang universal. Dari beberapa penjelasan tentang pendidikan karakter yang menekankan kepada beberapa prinsip sebagai berikut: yang pertama, adalah menanamkan nilai-nilai etika sebagai basis karakter. Kedua, mampu mengidentifikasi karakter secara keseluruhan supaya mencakup ranah pemikiran rendah perasaan dan ranah perilaku. Ketiga, menggunakan suatu pendekatan yang proaktif dan efektif untuk membangun karakter generasi muda. Keempat, menciptakan suatu komunitas di sekolah yang mempunyai sikap kepedulian baik ke sesama masyarakat bangsa dan negara.

Selanjutnya memberi kesempatan kepada peserta didik untuk dapat menunjukkan sikap dan perilakunya yang baik keenam memiliki suatu cakupan terhadap kurikulum yang bermakna dan menantang yang menghargai semua peserta didik. Dunia pendidikan merupakan suatu media yang tersusun sistematis dan efek aktif untuk menanamkan dan mengembangkan karakter peserta didik. Pembentukan karakter merupakan salah satu tujuan dari pendidikan nasional adalah mengembangkan potensi peserta didik untuk mempunyai kecerdasan, kepribadian dan akhlak yang mulia.

Pemanfaatan media dan kreativitas seorang pendidik sangat diperlukan, dengan cara mengembangkan potensi yang mereka miliki dan mengaplikasikannya kedalam akivitas pembelajaran. Tidak terdapat ketentuan yang dikeluarkan tentang bagaimana cara tertentu untuk menanamkan nilai-nilai karakter kepada peserta didik dalam sebuah pembelajaran, akan tetapi hal yang terpenting ialah Bagaimana nilai-nilai 
karakter tersebut dapat tersampaikan oleh peserta didik, dipahami, tertanam dan diharapkan dapat menjadi perilaku yang tetap dalam setiap diri peserta didik.

\section{SIMPULAN}

Keterlibatan orang tua dan guru mempunyai peran yang sangat penting dalam penanaman dan pengembangan pendidikan karakter kepada anak/peserta didik selama mereka ada di rumah dan sebagai peserta didik berada di sekolah. Guru secara individu maupun kelompok dituntut untuk mampu memberikan pendidikan karakter kepada peserta didik secara klasik maupun secara pribadi. Keteladanan dalam kemampuan untuk mendengarkan dan membuka ruang komunikasi dengan siswa selayaknya menjadi prioritas di dalam memperkuat karakter, sikap, dan perilaku anak/siswa. Orang tua di rumah memberikan contoh-contoh dan mendampingi anak-anak mereka dalam rangka mendukung pembentukan karakter anak mereka yang lebih baik, mandiri, dan bertanggung jawab. Selain itu juga guru dapat berkoordinasi dengan seluruh komponenkomponen sekolah yang ada untuk menanamkan dan menguatkan karakter di lingkungan sekolah tersebut. Media pembelajaran merupakan tempat menyalurkan pesan dan informasi dalam proses pembelajaran media pembelajaran dirancang untuk membantu peserta didik dalam mencerna dan memahami isi materi pelajaran, fungsi media dan kegiatan pembelajaran bukan hanya sekedar sebagai alat bantu bagi akan tetapi karakteristik media pembelajaran tersebut juga memengaruhi bagaimana keberhasilan dalam proses pembelajaran. Orang tua dan guru di dalam meningkatkan kemampuan diri mereka dalam segi kemampuan untuk mendengarkan dan membuka ruang komunikasi bagi anak/siswa untuk berdiskusi maupun bercerita sudah saatnya diimplementasikan karena perubahan teknologi, informasi, dan komunikasi bergerak sangat cepat dan anak/siswa membutuhkan pendampingan tersebut untuk mempersiapkan diri mereka dalam konteks kehidupan global era modern.

\section{DAFTAR PUSTAKA}

Alifah, M., Adha, M.M., Perdana, D.R., Hartino, A.T., \& Rifai, A. (2021). Upaya Meningkatkan Karakter disiplin Peserta Didik pada Pembelajaran daring di Masa Pandemi Covid-19. Prosiding Konferensi Nasional Kewarganegaraan (KNKn) KeV, Program Studi Magister Pendidikan Pancasila dan Kewarganegaraan (PPKn) Pascasarjana Universitas Negeri Yogyakarta (UNY) dengan Asosiasi Profesi Pendidikan Pancasila dan Kewarganegaraan Indonesia (AP3KnI).

Berkowitz, M. W \& Bier M. C. (2005). Work in Character Education: A rearch-Driven Guide for Educators. Washington DC: University Missourl-St Louis.

Butho, Z. A. (2016). Pengembangan Kompetensi Profesionalisme Guru PAI di Aceh. Jurnal Ilmu-Ilmu Keislaman, 40(2): 370-389.

Blyznyuk, T. (2008). Formation of Teacher Digital Competence: Dosmetic Challenges and Foreign Experience. Journal of Vasyl Stefanyk Precarpathian National University, 5(1), 40-46.

Fry, H., Ketteridge, S., \& Marshall, S. (2003). Understanding Student Learning. Hand Book for Teaching and Learning in Higher Education: Enhancing Academic Practice. New York: Rountledge.

Hartino, A.T., Adha, M.M., Rifai, A., Ulpa, E.P., \& SUpriyono. (2021). Eksistensi Pendidikan Kewarganegaraan dalam Meningkatkan Civic Responsibility di Masa Pembelajaran Daring. Prosiding Konferensi Nasional Kewarganegaraan (KNKn) Ke-V, Program Studi Magister Pendidikan Pancasila dan Kewarganegaraan (PPKn) Pascasarjana Universitas Negeri Yogyakarta (UNY) dengan Asosiasi Profesi Pendidikan Pancasila dan Kewarganegaraan Indonesia (AP3KnI).

Hasan, (2010). Pengembangan Pendidikan Budaya Dan Karakter Bangsa. Jakarta: Litbang Puskur.

Kementerian Pendidikan dan Kebudayaan. (2008). Kompetensi Guru di Era 4.0. Jakarta: Kementrian Pendidikan dan Kebudayaan. 
Majelis Luhur Persatuan Tamansiswa (MLTP). (2013). Ki Hadjar Dewantara: Pemikiran, Konsepsi, Keteladanan, Sikap Merdeka. Yogyakarta: Universitas Sarjanawiyata Tamansiswa.

Lickona, T. (1991). Educating for Character. New York: Bantam Books.

Lickona, T. (2012). Character Matter: Bagaimana Membantu Anak Mengembangkan Penilaian Yang Baik, Integritas, dan Kebajikan Penting Lainnya. Jakarta: Bumi Aksara.

Perdana, D.R \& Adha, M.M. 2020. Implementasi Blended Learning Untuk Penguatan Pendidikan Karakter Pada Pembelajaran Pendidikan

Kewarganegaraan. Citizenship Jurnal Pancasila dan Kewarganegaraan, 8 (2), 89-101.

Purwono, J., Yutmini, S., \& Anitah, S. (2014). Penggunaan Media Audio Visual Pada Ada Mata Pelajaran Ilmu Pengetahuan Alam di Sekolah Menengah Pertama Negeri Pacitan. Jurnal Teknologi Pendidikan dan Pembelajaran, 2(2), 127 144.

Sadiman, A. S. (1986). Media Pendidikan Pengertian Pengembangan dan Pemanfaatannya. Jakarta: CV Rajawali.

Sanjaya, W. (2006). Strategi Pembelajaran Berorientasi Standar Proses Pendidikan. Jakarta: Kencana Prenada Media Group.

Saputro, D. W., Pitoewas, B., \& Adha, M. M. (2013). Pengaruh Pendidikan Nilai Dalam Keluarga Terhadap Sikap Tanggung Jawab Siswa. Jurnal Kultur Demokrasi, 1 (9).

Sutisna, A. (2016). Pengembangan Model Pembelajaran Blended Learning Pada Pendidikan Kesetaraan Program Paket C Dalam Meningkatkan Kemandirian Belajar. Dalam meningkatkan Kemandirian Belajar. Jurnal Teknologi Pendidikan, 18(3), 156-168.

Tarmansyah, et. al. (2012). Pedoman Pengembangan Pendidikan Karakter Di Sekolah Inklusif. Padang: Direktorat pembinaan pendidikan khusus dan layanan khusus (PK-LK) Direktorat Pendidikan Dasar.
Wijaya, A.K., Giyono, U., \& Adha, M.M. (2020). Kontribusi Pembelajaran Pendidikan Kewarganegaraan Menggunakan Model Role Playing untuk Pengembangan Keterampilan Intelektual Siswa. Jurnal Pendidikan Pancasila dan Kewarganegaraan, 1 (2), 130-139.

Zulyan, S. V., Pitoewas, B., \& Adha, M. M. (2014). Pengaruh Keteladanan Guru Terhadap Sikap Belajar Peserta Didik. Jurnal Kultur Demokrasi, 2(2).

Undang-Undang Nomor 20 Tahun 2003 Tentang Sistem Pendidikan Nasional.

Undang-Undang Nomor 12 Tahun 2005 Tentang Guru dan Dosen. 